\title{
Asymmetric Impact of Oil Price on Inflation in Nigeria
}

\author{
Sani Bawa, Ismaila S. Abdullahi, Danlami Tukur, Sani I. Barda, and Yusuf J. \\ Adams ${ }^{1}$
}

This study examines the impact of oil price shocks on inflation in Nigeria. A NonLinear Autoregressive Distributed Lag (NARDL) approach was applied on quarterly data spanning 1999Q1 to 2018Q4. Results showed that oil price increases led to increase in headline, core and food measures of inflation in Nigeria. However, a decline in oil price resulted in a decline in the marginal cost of production and culminated in moderation of domestic inflation. Furthermore, negative oil price shocks led to higher inflation in Nigeria when exchange rate is dropped from the models, indicating that exchange rate absorbed the impact of oil price declines earlier, as lower oil prices culminated in lower external reserve, depreciation of the naira and ultimately higher inflationary pressures. Also, core inflation tends to respond more to oil price increases than food inflation. These results were robust to changes in econometric specifications and sample period. The study recommends that monetary policy actions of the Central Bank of Nigeria should focus on taming core inflation in periods of substantial oil price increases while strengthening its efforts at ensuring domestic sustainability in food production through its agricultural intervention programmes to further minimize the impact of international oil prices on food inflation. Similarly, the fiscal authorities should ensure that the fiscal stance is not excessively procyclical in periods of rising oil prices .

Keywords: Asymmetry, inflation, nonlinear autoregressive distributed lag, oil price shocks JEL Classification: E31, Q43

DOI: $10.33429 /$ Cjas.11220.4/8

\section{Introduction}

Crude oil remains the world's most important source of energy in the last seven decades, with its products serving as sources of energy for industries, homes, vehicles and airplanes ${ }^{2}$. Consequently, sudden disruptions in oil supplies and sharp increases in its prices are among the most important shocks hitting world economies. Oil has remained an important commodity that drives economic activities globally, and thus, oil price movements are a major determinant of macroeconomic outcome across countries.

\footnotetext{
${ }^{1}$ Authors are staff of the Central Bank of Nigeria.

The views/opinions expressed in this paper are those of the authors and do not in any way represent the views of the Central Bank of Nigeria.

${ }^{2}$ UK Oil and Gas https://www.ukogplc.com/page.php?pID=74
} 
Nigeria is endowed with abundant oil and gas resources, which production accounted for an average of one-fourth of its GDP from 1981 to 2018. Similarly, oil exports constituted about 95.7 percent of total exports, while oil revenues accounted for an average of 73.3 percent of government collected revenues during the same period. Consequently, the country's macroeconomic performance has been strongly associated with the oil sector.

Although Nigeria remains Africa's largest oil producer, the country has inadequate refining capacity and imports refined petroleum products to satisfy domestic demand. Thus, government subsidises petroleum products to maintain a regulated price irrespective of changes in international crude oil prices and the exchange rate. While this has severely constrained the government's fiscal space overtime, it has ensured that rising oil prices do not spill over to domestic prices of refined oil products, thereby minimizing its impact on consumer prices.

Nigeria's economy has largely been insulated from the direct impact of oil price changes through the fuel subsidies, though it has the tendency to suffer from inflationary pressures resulting from increases in the cost of producing imported goods when oil price increases in the international market. Available data on international trade statistics ${ }^{3}$ indicated that the country imported most of its consumer and capital goods worth about US $\$ 44.0$ billion (10.4 percent of GDP) in 2018.

Symmetric shocks are disturbances that generate uniform effects on a set of macroeconomic variables, that is, positive or negative shocks tend to cause movements in the variables in the same direction. However, disturbances due to asymmetric shocks induce macroeconomic variables to move in different directions. Consequently, a symmetric association between oil prices and inflation would imply that the same oil price/inflation elasticity applies to both increases and reductions in oil prices. Asymmetric relations between the two variables indicate that rise in oil prices could have a different impact on inflation from decline in oil prices.

Positive oil price shocks have the tendency to increase money supply in oil producing countries (Oyeyemi, 2013; Omolade, Ngalawa \& Kutu, 2019) with profound implications on consumer prices. Also, falling oil prices weaken the foreign earnings of oil producing countries resulting in currency depreciation and rising inflation (Bala \& Chin, 2018). Thus, oil

\footnotetext{
${ }^{3}$ Compiled by the External Sector Statistics Division of the Central Bank of Nigeria
} 
price shocks, whether positive or negative, have profound implications on consumer prices in oil producing countries including Nigeria.

Previous empirical studies such as Olusegun (2008) and Odionye, Ukeje and Odo (2019) focussed on the impact of oil price shocks on inflation at the aggregate level utilizing symmetric approaches. These approaches assume that changes in oil prices at the international market affect inflation in the same direction, without distinguishing the impact of an increase or a decrease in oil prices on inflation. However, the empirical association between oil prices and economic activity may not be symmetrical as positive and negative oil price shocks may have distinct impacts on economic activity (Mory, 1993). Consequently, it would be inappropriate to presume that the behaviour of inflation in response to oil price shocks is symmetric (Omolade et al. 2019). Empirical works including Kelikume (2017), Bala and Chin (2018) and Omolade et al. (2019) address this problem by adopting asymmetric approaches to examine the impact of oil price shocks on aggregate inflation in Africa's oil producing countries including Nigeria. In this study, we also examine the impact of oil price shocks on consumer price inflation in Nigeria. However, oil price increases could have a larger impact on core than food measure of inflation because most of the food consumed is produced locally and thus, its prices are largely immune from oil price induced inflation. Given this, we decompose inflation into the headline, core and food components to examine how oil price shocks influence each of the inflation categories. The paper contributes to the debate on which measure of inflation should be relevant for monetary policy response in periods of oil price shocks. We adopt a Nonlinear Autoregressive Distributed Lag (NARDL) model advanced by Shin, Yu and Greenwood-Nimmo (2014) as it allows for the evaluation of the potential long-run and short-run asymmetries in the relationship between oil prices and the three components of inflation.

The rest of the paper is structured as follows: Section 2 reviews the literature and Section 3 contain the data and methodology, while Section 4 discusses the empirical results. Section 5 concludes the study and presents policy recommendations.

\section{Literature Review}

\subsection{Theoretical Literature}

Higher oil prices impact the economy in a number of ways: transfer of income from oil importing economies to oil exporters; rise in the cost of production of goods and services 
in an economy emanating from an upsurge in the relative price of energy inputs; it impacts on the price level; decline in economy's productive capacity as producers respond to higher oil prices by reducing their utilization of both oil and capital; and uncertainty in investment decisions by households and firms owing to uncertain oil prices in the future. Others include direct and indirect impacts on financial markets and the incentive for providers of energy to increase production and investment (Fried \& Schultze, 1975; Marquez, 1986; Blanchard \& Gali, 2007; DePratto et al., 2009; Bataa, 2010; Alvarez et al., 2011; Trang et al., 2017; Bala $\&$ Chin, 2018). The magnitude and direction of its impact, however, differ between industrial and developing countries as well as between oil producing and consuming economies (IMF, 2000).

Oil price shocks affect domestic inflation in countries through both direct and indirect channels: directly through increases in prices of refined oil products, which spill over to the Consumer Price Index (CPI), and indirectly through price changes in goods and services, which utilize oil or oil products as inputs in the production process (Zivkov, Duraskovic \& Manic, 2019). The direct impact would depend, among others, on the expenditure share of households on refined oil products over total expenditure. Alvarez et al. (2011) have shown that the direct impacts tend to exhibit higher pass-through to inflation than the indirect impacts. Meanwhile, inflationary pressures emanating from rising oil prices through these channels (first round effects) may trigger behavioural responses from firms and workers, leading to revision of inflation expectations, increase in nominal wages, transferring the marginal increase in cost of production to consumers and further changes in the price level through the second round effects.

Corroborating this, Conflitti and Luciani, (2017) states that oil price hikes may have an inflationary effect in four ways - increase in production costs, higher inflation expectations, demand for higher wages by workers to compensate for the increase in energy prices and an adverse supply shock if real wages do not decrease sufficiently, thus triggering an adjustment in employment. However, it can have a deflationary effect through a demand shock as higher oil prices tend to reduce net disposable income, hence consumption and investment.

\subsection{Empirical Literature}

Several empirical studies have investigated the relationship between oil price fluctuations and economic activity. Earlier attempts include Hamilton (1983, 1996, 2005), which pro- 
vide evidence on a robust relationship between oil price increases and subsequent economic downturns in the United States (US) particularly after the Second World War. In Nigeria, Aliyu (2009) establishes an asymmetric impact of oil price shocks on real GDP, with positive changes having larger impact on real GDP than negative changes. Alhassan and Kilishi (2016) have also shown that oil price shocks led to macroeconomic fluctuations in Nigeria. Narrowing down to inflation, Hooker (2002) finds evidence that fluctuations in oil prices contributed to the increase in US core inflation before 1981 and reduced afterward. Since then, several studies have investigated the relationship between oil prices and inflation in both advanced and developing economies utilizing different methodologies.

Studies such as Brown, Oppedahl and Yucel (1995); Dias (2013); Lu, Liu and Tseng (2013); Zhao et al. (2016); Conflitti and Luciani (2017); and Zivkov, Duraskovic and Manic (2019) reported significant positive impact of oil prices on inflation in advanced countries. Utilizing a vector autoregression (VAR) model and US data, Brown et al. (1995) have shown that oil price shocks influence output and the price level, though, the country's monetary policy was able to accommodate the inflationary pressure from the shocks. Similarly, Dias (2013) estimates the effects of oil price shocks on economic variables including GDP, employment and inflation using a structural VAR model for the Portuguese economy during the 1984 2012 period. Results from impulse response functions (IRFs) indicated, among others, that an increase in oil prices of approximately 13 per cent, translated into higher inflation by 0.25 and 0.05 percentage points in the first and second period, respectively. However, the impact reduces slowly from the third period, with virtually no long-term effect on the price level.

Lu et al. (2013) examined the effect of oil price shocks on inflation in Taiwan utilizing a bivariate GARCH approach and data covering the 1986 - 2008 period. They reported that oil prices strongly Granger-caused inflation in Taiwan and revealed a persistent volatility spillover from oil price to inflation during the period. Zhao et al. (2016) built an open-economy dynamic stochastic general equilibrium (DSGE) model for the Chinese economy to assess the impact of oil price shocks on output and inflation. The study categorized four types of oil price shocks to include supply shocks driven by political events in OPEC countries, other oil supply shocks, aggregate shocks to the demand for industrial commodities, and demand shocks that are specific to the crude oil market. They revealed that the first shock mainly accounts for short-term changes to output and inflation in China, while the other three shocks 
lead to relatively long-term effects. Demand shocks that are specific to the crude oil market add the most to the variations in China's output and inflation.

Conflitti and Luciani (2017) examined the oil price pass-through to inflation in both the US and Euro area utilizing dynamic factor models and VAR. After distinguishing between the common and idiosyncratic effects of oil price shocks on inflation, the study showed that oil price influences inflation mainly through the common effect, the pass-through was small, though, it was significant and long lasting. Zivkov et al. (2019) also found that the passthrough of oil prices to inflation was relatively slow in eleven Central and Eastern European countries (the Czech Republic, Poland, Hungary, Slovakia, Lithuania, Latvia, Estonia, Romania, Bulgaria, Slovenia and Croatia) during the 1996 - 2018 period. An increase in oil price by 100 percent was followed by a rise in inflation of $1-6$ percentage points. Two countries (Slovakia and Bulgaria) that had the highest oil import/GDP ratios tended to have the highest and most consistent pass-through effects in the analysis.

Empirical works also abound in developing countries. For instance, Niyimbanira (2013) established a cointegrating relationship between oil prices and inflation in South Africa with unidirectional causality from oil prices to inflation. Shafique (2016), however, could not find any effect of crude oil price shocks on the producer price index of an oil importing economy of Pakistan.

A number of studies investigate the impact of oil price shocks on oil producing economies. Utilizing a VAR framework, Ito (2010) reveals that Russia is vulnerable to oil price shocks, as it contributed to a mild inflation in the short-run in addition to its impact on exchange rate and national output. Similarly, Abounoori, Nazarian and Amiri (2014) examines the nature and causes of oil price pass-through into inflation in Iran. Results from their analysis show a positive and incomplete pass-through in both the short and long term, indicating that oil price hikes lead to increase in inflation in Iran. In a comparative study, Sek, Teo and Wong (2015) and Sek and Lim (2016) distinguished between high and low oil-dependent countries and investigated the impact of oil price shocks on inflation in the two groups of countries. Utilizing a panel ARDL framework, Sek, Teo and Wong (2015) discovered that the impact was distinct between the two groups - tended to be more severe for the high oil dependency group than the low oil dependency group, which are mostly oil producers. Sek and Lim (2016) also found that CPI inflation in oil exporting countries does not respond to oil supply 
and demand shocks, whereas supply shocks can be a strong determinant of inflation in oil importing countries.

In Nigeria, Olusegun (2008) had shown that oil price shocks significantly contributed to variations in oil revenues and national output. However, he opined that oil price shocks may not necessarily be inflationary, but recommended the application of fiscal policy measures in restoring stability in the domestic economy in the aftermath of an oil shock. Similarly, Odionye et al. (2019) had shown that the response of inflation to oil price shocks was negative at the initial instance, before turning positive after two periods. However, the exchange rate's response to oil price shocks was negative and persistent. Omotosho and Doguwa (2012) found that the announcement of fuel price hikes, food crises, exchange rate instability and upward review of wages of public sector employees were the major factors that caused high inflation volatility in Nigeria. Thus, subsequent withdrawal of fuel subsudies in Nigeria and increases in the international prices of crude oil would culminate in higher domestic fuel prices and inflationary pressures in the country.

The foregoing review considers the relationship between oil price shocks and inflation as symmetric, implying that the oil price/inflation elasticity applies to both increase and decrease in oil prices in the same direction. However, oil prices may have asymmetric effects on economic outcomes (Mork, 1989; Mory, 1993) such that positive oil price shocks have a distinct impact from negative oil price shocks on economic activities. Several studies have examined the asymmetric impact of oil price shocks on inflation across many countries, by partitioning oil price shocks into positive and negative shocks. Cunado and de Gracia (2005) have shown that oil price shocks impacted on both consumer prices and economic activity in six Asian countries - Japan, Singapore, South Korea, Malaysia, Thailand and Philippines, even though the impact was limited to the short-run and more pronounced when oil price shocks are defined in local currencies. In addition, they find evidence of asymmetries in the relationship between oil price shocks and inflation in four countries. Utilizing an unbalanced panel of 72 developed and developing economies, Choi et al. (2018) showed that a 10 percent increase in global oil inflation, would, on average, increase domestic inflation by about 0.4 percentage point, with the effect vanishing after two years. They revealed that the effect is asymmetric, with positive oil price shocks having a larger impact on inflation than the negative ones. On the transmission channel for the shocks, their results indicated that the share 
of transport in the CPI basket and energy subsidies are the most important factors explaining cross-country variations in oil price shocks.

Ibrahim (2015), Abdlaziz, Rahim and Adamu (2016) and Lacheheb and Sirag (2019) applied the NARDL approach to examine the oil price-inflation nexus in Malaysia, Indonesia and Algeria. Ibrahim (2015) found that food price, oil price and real GDP were cointegrated with asymmetries in the food price behaviour in Malaysia. The study established a significant relationship between oil price hikes and increases in food prices in both the long and shortrun, but could not find any significant influence of oil price decline on food prices both in the long-and short-run. Abdlaziz, Rahim and Adamu (2016) revealed evidence of a strong positive relationship between food and oil price increase in both the long-run and short-run. Their results indicated that a 10 percent increase in oil prices induced a 3.6 percent rise in food prices in the long-run. Lacheheb and Sirag (2019) also found a non-linear effect of oil price on inflation, with oil price increases significantly impacting on inflation, while oil price declines do not have a significant impact.

In Nigeria, Kelikume (2017) examined the asymmetric effect of exchange rate and oil price shocks on inflation utilizing a vector error correction methodology (VECM). The study found, among others, that oil price hikes induced a 43 percent increase in inflation in a year, while a fall in oil prices leads to a 29 percent increase in inflation. Bala and Chin (2018) estimates the asymmetric impacts of oil price shocks on inflation in four African oil producing countries - Algeria, Angola, Libya and Nigeria using the ARDL dynamic panels framework. The study discovered that both positive and negative oil price shocks positively influence inflation in these countries during the period, but the impact was more pronounced in periods of oil price declines. Similarly, Omolade et al. (2019) applied a panel structural VAR framework and found that a sharp decline in oil prices has been accompanied by an increase in inflation in eight Africa's oil producing countries including Nigeria. The study revealed that the increase in inflation that followed these declines was more structural than monetary in nature.

Utilizing a New-Keynesian DSGE model to examine the macroeconomic implications of oil price shocks and the fuel subsidy regime in Nigeria, Omotosho (2019) discovered that oil price shocks impacted on headline inflation, though, the contribution was minimal owing to incomplete pass-through of international oil prices to domestic fuel price. The study revealed 
that a negative oil price shock generated lower marginal cost and culminated in a fall in domestic inflation. However, a depreciation in the domestic currency following a fall in oil prices caused import prices to rise, culminating in increases in the headline and core measures of inflation.

Overwhelming evidence from the review suggests that oil price shocks induce inflationary pressures, particularly in oil importing countries. However, utilizing asymmetric approaches further reveals that positive oil price shocks tend to have higher impact on consumer prices than the negative ones. Studies on Nigeria dwelt on the impact of oil price shocks on headline inflation. But the impacts of oil price shocks on the core and food measures of inflation in Nigeria could be different as most commodities included in computing core inflation are imported and their prices are vulnerable to changes in oil prices unlike commodities included in food inflation which are mostly produced locally. This study therefore contributes to the literature by investigating the impact of oil price shocks on headline, core and food inflation in Nigeria utilizing asymmetric approach.

\subsection{Trends in Crude Oil Prices and Inflation in Nigeria ${ }^{4}$}

Unlike most commodities, fluctuations in crude oil prices are not entirely determined by the laws of demand and supply, but market sentiments towards oil futures and a host of other economic and political factors. Data from the World Bank commodity prices database shows that crude oil witnessed significant fluctuations overtime with the Brent crude price recording an average of US\$31.0 per barrel during the period 1999 - 2005. Reasons given for low oil prices include weak demand from Asia, increased supply from the Organization of Petroleum Exporting Countries (OPEC), fear of increasing production from the Middle East and shaky global economy and weak consumer confidence in the aftermath of the attacks in the US in September 2001. Even though headline inflation remained at single-digit in 1999 and 2000, it increased significantly to 18.90 per cent in 2001 and averaged 13.3 per cent during 1999 2005 period.

Oil prices rose significantly to an average of US\$75.4 per barrel during $2006-2010$ period due to increasing geopolitical tensions, activities of speculators and a slide in the value of the

\footnotetext{
${ }^{4}$ All data on oil prices (Brent crude) in this section are sourced from the World Bank commodity prices database (pink sheet) while data on inflation are sourced from the National Bureau of Statistics (NBS)
} 
United States dollar, among others. While it recorded US\$90.69 per barrel in January 2008, the price declined significantly in the second half of 2008 owing to the global financial crisis and the accompanying uncertainties across the world. Consequently, exchange rate remained largely stable during the period 2006 - 2010 as higher oil prices led to higher inflow of foreign exchange and higher external reserves position. Thus, average inflation moderated to 10.3 percent during the period on account of the relative stability in the exchange rate and the stability in the prices and supply of petroleum products as well as good agricultural harvest. The rising demand for crude oil led to substantial increase in prices, reaching US $\$ 107.7$ per barrel during the 2011 - 2014 period, while headline inflation declined further to 9.9 per cent during the period.

However, the global commodity shocks of 2014 - 2015 led to a significant decline in oil prices, with Brent crude recording an average of US\$52.37 per barrel in 2015. Increase in global supplies had pushed the price further to US $\$ 44.05$ per barrel in 2016 . However, prices increased to US\$71.07 per barrel in 2018, continuing the recovery in 2017 , owing to increasing demand. The commodity shocks culminated in a significant decline in foreign exchange inflows and external reserve accumulation in Nigeria leading to the depreciation of the domestic currency and heightened inflationary pressures. Consequently, headline inflation trended upwards to 13.3 percent during the 2015 - 2018 period.

Thus, Nigeria's inflation experience has largely reflected developments in crude oil prices over the years. The analysis showed that negative oil shocks have been followed by declining foreign exchange inflows and reserve accumulation, subsequently leading to exchange rate instability and rising inflationary pressures. However, rising oil prices culminated in stable exchange rates and a moderation in inflation. This largely indicates that positive and negative oil price shocks have distinct impacts on inflation in Nigeria. 


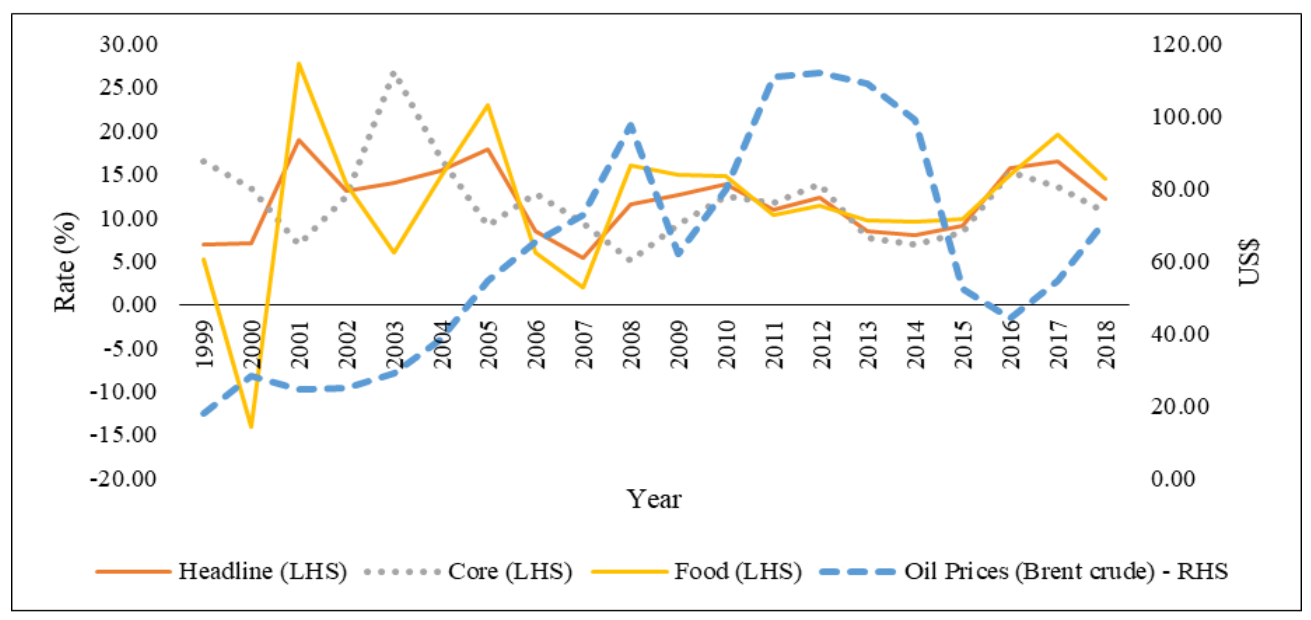

Figure 1: Average oil prices vs average headline, food and non-food inflation in Nigeria, 1999-2018

\section{Data and Methodology}

\subsection{Data}

This study employed quarterly data for the period 1999Q1 to 2018Q4 in the analysis. The data set utilized include the three measures of inflation - headline, core and food inflation (sourced from the National Bureau of Statistics); broad money supply, real GDP (2010 base year), nominal exchange rates and average rainfall, which were extracted from the 2018 edition of the Central Bank of Nigeria's Statistical Bulletin and Statistics database obtainable at

statistics.cbn.gov.ng/cbn-onlinestats/. For oil prices, Brent crude prices in US\$ were used, and were sourced from the commodity prices database (the pink sheet) of the World Bank. The Hodrick-Prescott (HP) filter was used to estimate the output gap.

\subsection{Theoretical Framework}

The New Keynesian model has been utilized as the standard framework for analysing the interactions between macroeconomic variables. Blanchard and Gali (2007), Blanchard and Riggi (2013) and Rondina (2017) incorporated the effects of oil prices on output and inflation within the New Keynesian Phillips Curve (NKPC) framework. The NKPC describes a relationship between inflation, the expectations that firms hold about future inflation and the real marginal cost of production. It indicates that inflation would tend to rise owing to increase in real marginal costs as firms pass on higher costs to the prices of their products, as well as expectations of higher inflation in the future resulting in firms raising their prices today. 
Calvo (1983) pioneered the basic NKPC model stated as follows:

$$
\pi_{t}=\beta E_{t} \pi_{t+1}+\lambda m c_{t}
$$

where $\pi_{t}$ is the inflation rate, $E_{t} \pi_{t+1}$ is the expected inflation and $m c_{t}$ is the real marginal cost of production. Replacing expected inflation with the past values of inflation and monetary aggregates and considering the fact that real marginal costs are proportionately related to output gap (see Rotemberg \& Woodford, 1999; Cevik \& Teksoz, 2013; Bawa, Abdullahi \& Ibrahim, 2016), the new NKPC model now becomes:

$$
\pi_{t}=\alpha \pi_{t-1}+\beta m_{t-1}+\gamma\left(y_{t}-y_{t}^{*}\right)
$$

where $\pi_{t-1}$ is the lagged inflation, $m_{t-1}$ is the lagged money supply growth, and $\left(y_{t}-y_{t}^{*}\right)$ is the output gap. We augmented equation 2 with other variables that influence inflation including crude oil prices, nominal exchange rate and average rainfall to determine the impact of oil prices on inflation in Nigeria.

\subsection{Model Specification}

Bawa et al. (2016) utilizes the New Keynesian Phillips Curve (NKPC) methodology to arrive at a hybrid model of consumer price inflation for Nigeria. As Bello and Sanusi (2019) found the augmented NKPC model empirically useful in examining inflation dynamics in Nigeria, this study adopts the Bawa et al. (2016) model to analyse the impact of crude oil price on headline, core and food inflation. The model is specified as follows:

$$
\pi_{t}=\alpha_{0}+\beta_{1} \pi_{t-1}+\beta_{2} m_{t-1}+\beta_{3}\left(y_{t}-y_{t}^{*}\right)+\beta_{4} X_{t}+\mu_{t}
$$

where $\pi_{t}$ is the inflation rate at time $t$ and represents the three measures of inflation - headline, core and food, respectively, $\pi_{t-1}$ is one period lag of inflation, $m_{t-1}$ is one period lag of money supply growth, $\left(y_{t}-y_{t}^{*}\right)$ is output gap, which is the difference between actual output and potential output, $X_{t}$ is other control variables that impact on inflation in Nigeria and $\mu_{t}$ is the error term. $\alpha_{0}$ and $\beta_{i}$ are the parameters to be estimated. In equation $3, \alpha_{0}$ is the intercept while $\beta_{1}, \beta_{2}, \beta_{3}$ and $\beta_{4}$ are the respective parameters of the explanatory variables included in the model.

In the spirit of Bawa et al. (2016), the study includes three control variables - crude oil prices, nominal exchange rates and average rainfall to minimise omitted variable bias. Nominal exchange rate was included considering the impact of exchange rate pass-through on consumer 
prices. The role of rainfall in influencing food prices, which constitute a significant percentage of the CPI inflation in Nigeria, justified its inclusion in the model. This enables the study to examine the impact of oil price shocks on consumer price inflation in Nigeria. Thus, the linear model is as follows:

$$
\pi_{t}=\alpha_{0}+\beta_{1} \pi_{t-1}+\beta_{2} m_{t-1}+\beta_{3}\left(y_{t}-y_{t}^{*}\right)+\beta_{4} e r_{t}+\beta_{5} \text { oilp }_{t}+\beta_{6} \text { rain }_{t}+\mu_{t}
$$

where $e r_{t}$ is the nominal exchange rate, oilp $p_{t}$ is the average brent crude oil prices and rain is the average rainfall in Nigeria. To capture the asymmetric impact of oil price shocks on inflation, we specify a non-linear model by decomposing the variable oil $p_{t}$ into positive and negative shocks as follows:

$$
\operatorname{oilp}_{t}=\operatorname{oilp}_{0}+\operatorname{oilp}_{t}^{+}+\text {oilp }_{t}^{-}
$$

where oil $p_{0}$ is the constant term and oilp $p_{t}^{+}$and oilp $p_{t}^{-}$are the partial sums of the positive and negative changes in oil $p_{t}$, and are defined as follows:

$$
\begin{aligned}
& \ln (\text { oilp })_{t}^{+}=\sum_{j=1}^{t} \Delta \ln (\text { oil } p)_{j}^{+}=\sum_{j=1}^{t} \max \left(\Delta \ln \left(\text { oil }_{j}\right), 0\right) \\
& \ln (\text { oilp })_{t}^{-}=\sum_{j=1}^{t} \Delta \ln (\text { oilp })_{j}^{-}=\sum_{j=1}^{t} \min \left(\Delta \ln \left(\text { oil }_{j}\right), 0\right)
\end{aligned}
$$

Following Shin et al. (2014), we replace oilp $p_{t}$ in equation 4 with oilp $p_{t}^{+}$and oilp $p_{t}^{-}$to arrive at a non-linear ARDL model as stated below:

$$
\pi_{t}=\alpha_{0}+\beta_{1} \pi_{t-1}+\beta_{2} m_{t-1}+\beta_{3}\left(y_{t}-y_{t}^{*}\right)+\beta_{4} e r_{t}+\beta_{5} \text { oilp p}_{t}^{+}+\beta_{6} \text { oilp }_{t}^{-}+\beta_{7} \text { rain }_{t}+\mu_{t}
$$

From equation 8 , the relationship between past inflation and current inflation is positive. Similarly, the relationship between money supply and inflation is positive, in which case increases in money supply would lead to increases in inflation. In addition, positive output gap and exchange rate depreciation are all expected to impact positively on inflation, while higher rainfall would invariably result in higher food production and decline in food prices and ultimately, a decline in inflation. Meanwhile, the relationship between oil price increases and inflation is represented by $\beta_{5}$, which is expected to be positive. This indicates that, $a$ 
priori, increase in crude oil prices in the international market culminates in higher inflationary pressures. Similarly, the relationship between oil price declines and inflation is captured by $\beta_{6}$, and is expected to also be positive, implying that decline in oil prices leads to lower marginal cost of production and a fall in inflation. However, falling oil prices weaken the foreign exchange earnings of oil exporting countries which are import dependent, manifesting in the depreciation of the domestic currency and resulting in rising import prices and increase in domestic inflation (See Bala \& Chin, 2018; Omotosho, 2019). Consequently, $\beta_{6}$ can be negative in Nigeria.

\subsection{Estimation Procedure}

Shin et al. (2014) advocated a non-linear ARDL approach (NARDL) as an extension to the usual ARDL modelling technique developed by Pesaran, Shin and Smith (2001) to capture asymmetries in modelling. This study adopts the NARDL framework to assess long run and short run asymmetries in the relationship between oil price changes and consumer price inflation in Nigeria. Shin et al. (2014) justify applying Pesaran et al. (2001) bounds testing approach to the NARDL model in equation 8 .

Therefore, the NARDL model from equation 8 takes the following form:

$$
\begin{aligned}
\Delta \pi_{t}= & \alpha_{0}+\sum_{i=1}^{q} \beta_{1 i} \Delta \pi_{t-i}+\sum_{i=0}^{q} \beta_{2 i} \Delta m_{t-i}+\sum_{i=0}^{q} \beta_{3 i} \Delta\left(y_{t}-y_{t}^{*}\right)_{t-i}+\sum_{i=0}^{q} \beta_{4 i} \Delta e r_{t-i} \\
& +\sum_{i=0}^{q} \beta_{5 i} \Delta \text { oil }_{t-i}^{+}+\sum_{i=0}^{q} \beta_{6 i} \Delta \text { oil p}_{t-i}^{-}+\sum_{i=0}^{q} \beta_{7 i} \Delta \text { rain }_{t-i}+\delta_{1} \pi_{t-1}+\delta_{2} m_{t-1} \\
& +\delta_{3}\left(y_{t}-y_{t}^{*}\right)_{t-1}+\delta_{4} e r_{t-1}+\delta_{5} \text { oil }_{t-1}^{+}+\delta_{6} \text { oil }_{t-1}^{-}+\delta_{7} \text { rain }_{t-1}+e_{t}
\end{aligned}
$$

where model variables are as defined earlier, $\Delta$ is a first differenced operator, $\alpha_{0}$ is an intercept term, $\beta_{1}$ to $\beta_{7}$ are short run coefficients,,$\delta_{1}$ to $\delta_{7}$ are long run parameters and q being the optimal lag orders. Following Pesaran et al. (2001), we examined cointegration using the Wald test by testing for the joint significance of the long run parameters in equation 9 :

$$
\begin{aligned}
& H_{0}: \delta_{i}=0 \\
& H_{1}: \delta_{i} \neq 0 \forall i=1,2, \ldots, 7
\end{aligned}
$$

Pesaran et al. (2001) computed the two critical values (CV) for the test. If the computed F statistic is less than the lower bound CV, there is no cointegration. However, when computed F statistic is higher than the upper bound CV, the null hypothesis of no cointegration is rejected. But, when the F statistic is within the lower and upper bounds, the test is inconclusive. 
The long run model can then be specified from equation 9 as follows:

$$
\begin{aligned}
\pi_{t}= & \alpha_{0}+\sum_{i=1}^{q} \beta_{1 i} \pi_{t-i}+\sum_{i=0}^{q} \beta_{2 i} m_{t-i}+\sum_{i=0}^{q} \beta_{3 i}\left(y_{t}-y_{t}^{*}\right)_{t-i}+\sum_{i=0}^{q} \beta_{4 i} e r_{t-i} \\
& +\sum_{i=0}^{q} \beta_{5 i} \text { oil } t_{t-i}^{+}+\sum_{i=0}^{q} \beta_{6 i} \text { oil }_{t-i}^{-}+\sum_{i=0}^{q} \beta_{7 i} \text { rain }_{t-i}+e_{t}
\end{aligned}
$$

The short-run error correction model associated with equation 9 is specified as follows:

$$
\begin{aligned}
\Delta \pi_{t}= & \alpha_{0}+\sum_{i=1}^{q} \beta_{1 i} \Delta \pi_{t-i}+\sum_{i=0}^{q} \beta_{2 i} \Delta m_{t-i}+\sum_{i=0}^{q} \beta_{3 i} \Delta\left(y_{t}-y_{t}^{*}\right)_{t-i}+\sum_{i=0}^{q} \beta_{4 i} \Delta e r_{t-i} \\
& +\sum_{i=0}^{q} \beta_{5 i} \Delta \text { oil p}_{t-i}^{+}+\sum_{i=0}^{q} \beta_{6 i} \Delta \text { oil }_{t-i}^{-}+\sum_{i=0}^{q} \beta_{7 i} \Delta \text { rain }_{t-i}+\vartheta e c m_{t-1}+e_{t}
\end{aligned}
$$

where $\vartheta$ is the speed of adjustment parameter, while ecm is the residual series from the long run equation 10.

\section{Results and Discussion}

\subsection{Test for Unit Root}

The ARDL bounds testing approach requires that no variable integrated of order 2, that is $\mathrm{I}(2)$, are involved in the analysis. Consequently, we begin by undertaking unit root tests for all variables to determine their level of stationarity, using both Augmented Dickey-Fuller (ADF) and Phillips-Perron (PP) tests and the results presented in Table 1.

Table 1: Unit Root Tests

\begin{tabular}{lllll}
\hline \multicolumn{3}{c}{ ADF Test } & PP Test \\
\hline Variable & $\mathrm{I}(0)$ & $\mathrm{I}(1)$ & $\mathrm{I}(0)$ & $\mathrm{I}(1)$ \\
$\ln ($ cpih $)$ & -2.78 & $-5.03^{* *}$ & -2.96 & $-17.39^{* *}$ \\
$\ln ($ cpic $)$ & -2.57 & $-7.38^{* *}$ & -2.52 & $-8.54 * *$ \\
$\ln ($ cpif $)$ & -3.10 & $-5.75^{* *}$ & $-3.72^{*}$ & $-11.26^{* *}$ \\
$\ln (\mathrm{m})$ & -1.04 & $-9.51^{* *}$ & -0.89 & $-9.62^{* *}$ \\
qgap & -1.81 & -3.38 & $-11.40^{* *}$ & $-17.90^{* *}$ \\
$\ln (\mathrm{er})$ & -1.70 & $-6.36^{* *}$ & -1.31 & $-6.16^{* *}$ \\
$\ln ($ oilp $)$ & -2.25 & $-7.05^{* *}$ & -2.25 & $-6.90^{* *}$ \\
$\ln ($ rain $)$ & -2.75 & $-6.09^{* *}$ & $-12.93^{* *}$ & $-24.49 * *$ \\
\hline
\end{tabular}

The critical values for both $A D F$ and PP Tests at 5 percent and 1 percent were 3.47 and 4.08

* Significance at 5 per cent level, ** Significance at 1 per cent level

ADF test results indicate that all the variables are not stationary at levels. However, all the variables, except output gap (qgap) are found to be stationary after first differencing. The 
PP test shows that food inflation ( $\ln ($ cpif)), output gap (qgap) and average rainfall $(\ln ($ rain)) are stationary at level, while other variables would become stationary after first differencing. Thus, results from the tests indicate that the series exhibit different levels of stationarity and none of the variables are $\mathrm{I}(2)$, providing grounds for the adoption of the bound test procedure.

\subsection{Bounds Test for Cointegration}

The study conducts the bounds test proposed by Pesaran et al. (2001) to confirm if a longrun relationship exists among the variables in the model. The CVs for the test were provided for in Pesaran et al. (2001). The results of the ARDL bounds test for the three models are shown in Table 2.

Table 2: Bounds Test for Cointegration

\begin{tabular}{|c|c|c|c|c|c|c|c|}
\hline \multirow[t]{2}{*}{ Model } & \multirow[t]{2}{*}{ F-Stats } & \multirow[t]{2}{*}{$\begin{array}{l}\text { Sign. } \\
\text { Levels }\end{array}$} & \multicolumn{2}{|c|}{$\begin{array}{l}\text { Bound critical } \\
\text { values (Restricted } \\
\text { intercept and no } \\
\text { trend - Case II) }\end{array}$} & \multicolumn{2}{|c|}{$\begin{array}{l}\text { Bound critical } \\
\text { values (Unre- } \\
\text { stricted intercept } \\
\text { and no trend - } \\
\text { Case III) }\end{array}$} & \multirow[t]{2}{*}{ Decision } \\
\hline & & & $\mathrm{I}(0)$ & $\mathrm{I}(1)$ & $\mathrm{I}(0)$ & $\mathrm{I}(1)$ & \\
\hline Model 1 & 21.8124 & $1.0 \%$ & 2.88 & 3.99 & 3.15 & 4.43 & Co- \\
\hline $\begin{array}{ll}\ln (\text { cpih }), & \ln (\mathrm{m}), \\
\text { qgap, } & \ln (\mathrm{er}), \\
\ln \text { (oilp), } & \ln \text { (rain) }\end{array}$ & & $2.5 \%$ & 2.55 & 3.61 & 2.75 & 3.99 & integration \\
\hline $\begin{array}{l}\text { Model } 2 \\
\ln (\text { cpic }), \quad \ln (\mathrm{m}), \\
\text { qgap, } \\
\ln (\text { oilp } \text { (er), } \ln \text { (rain) }\end{array}$ & 6.0435 & $5.0 \%$ & 2.27 & 3.28 & 2.45 & 3.61 & $\begin{array}{l}\text { Co- } \\
\text { integration }\end{array}$ \\
\hline $\begin{array}{l}\text { Model } 3 \\
\ln \text { (cpif), } \ln (\mathrm{m}), \\
\text { qgap, } \\
\ln \text { (oilp), } \ln (\text { rain }),\end{array}$ & 6.7421 & $10.0 \%$ & 1.99 & 2.94 & 2.12 & 3.23 & $\begin{array}{l}\text { Co- } \\
\text { integration }\end{array}$ \\
\hline
\end{tabular}

Results from the bounds test for model 1 shows that the six variables co-move in the long run. The calculated F-statistic of 21.8124, is above the upper bound CVs at 1 percent levels using both case II and case III, suggesting the presence of cointegrating relationship among the variables. Similarly, the hypotheses of no cointegration amongst the variables in models 2 and 3 were rejected, as the respective F statistics are above the upper bound critical values under both models. 


\subsection{Estimation Results}

Having found evidence of cointegration relationship in the models, we assess inflation dynamics and examine the impact of positive and negative changes in oil prices on consumer price inflation in Nigeria. Consequently, this study estimated both the long-run and short-run models by utilizing a maximum lag length of 3 . The Akaike Information Criterion (AIC) was used to choose the optimal lags. The results of the long-run models are presented in Table 3, with the impact of oil price changes on headline, core and food inflation separated into two positive and negative changes.

Table 3: Estimated Long-run Model

\begin{tabular}{|c|c|c|c|}
\hline $\begin{array}{l}\text { Dependent } \\
\text { Variable }\end{array}$ & $\ln ($ cpih) & $\ln ($ cpic $)$ & $\ln$ (cpif) \\
\hline Variable & Model 1 & Model 2 & Model 3 \\
\hline $\mathrm{c}$ & $\begin{array}{l}-2.0244 * * * \\
(0.7044)\end{array}$ & $\begin{array}{l}-0.9301 \\
(1.4776)\end{array}$ & $\begin{array}{l}-2.0896 * * \\
(0.9270)\end{array}$ \\
\hline $\ln ($ oilp)_pos & $\begin{array}{l}0.1244 * * \\
(0.0508)\end{array}$ & $\begin{array}{l}0.2052^{*} \\
(0.1040)\end{array}$ & $\begin{array}{l}0.1165^{*} \\
(0.0666)\end{array}$ \\
\hline $\ln$ (oilp)_neg & $\begin{array}{l}0.0499 \\
(0.0405)\end{array}$ & $\begin{array}{l}0.0607 \\
(0.0859)\end{array}$ & $\begin{array}{l}0.0260 \\
(0.0527)\end{array}$ \\
\hline $\ln (m)$ & $\begin{array}{l}0.2476 * * * \\
(0.0634)\end{array}$ & $\begin{array}{l}0.1218 \\
(0.1345)\end{array}$ & $\begin{array}{l}0.2503 * * * \\
(0.0834)\end{array}$ \\
\hline qgap & $\begin{array}{l}0.0127 * * * \\
(0.0027)\end{array}$ & $\begin{array}{l}0.0182 * * * \\
(0.0055)\end{array}$ & $\begin{array}{l}0.0118 \text { *** } \\
(0.0035)\end{array}$ \\
\hline $\ln (\mathrm{er})$ & $\begin{array}{l}0.8036 * * * \\
(0.0984)\end{array}$ & $\begin{array}{l}0.8269 * * * \\
(0.1995)\end{array}$ & $\begin{array}{l}0.8084 * * * \\
(0.1286)\end{array}$ \\
\hline $\ln$ (rain) & $\begin{array}{l}0.0245 \\
(0.0171)\end{array}$ & $\begin{array}{l}-0.0538 \\
(0.0562)\end{array}$ & $\begin{array}{l}0.0180 \\
(0.0235)\end{array}$ \\
\hline
\end{tabular}

The models show that the coefficients of oil price increase have the anticipated positive signs and significant impacts on headline, core and food inflation in Nigeria. The results from the three models reveal that a 1 percent increase in oil price lead to 0.12 percent, 0.21 percent and 0.12 percent increase in headline, core and food inflation, respectively. The rise in inflationary pressure induced by increase in international oil price largely emanates from the passthrough of global inflation (induced by the oil price hike) to domestic inflation, economic boom in periods of high oil prices in oil exporting countries including Nigeria, increase in money supply owing to higher inflow of oil proceeds, among others. These results are similar 
to those of Kelikume (2017) as well as Bala and Chin (2018) which found that positive oil price shocks were inflationary in Nigeria. Similarly, Choi et al. (2018) and Lacheheb and Sirag (2019) also discovered that positive oil price shocks culminated in inflationary pressures and have larger and significant impact than negative oil price shocks. In addition, oil price increases tend to have a higher impact on core inflation than food inflation in Nigeria during the period. This is so because most of the food consumed is usually produced in the country and thus, its prices are largely immune from oil price induced inflation. The results also indicate that the coefficients of oil price declines were positive, but not significant, indicating that negative oil price shocks may lead to reduction in domestic inflation in Nigeria. It shows that a 1 percent drop in oil prices lead to 0.05 percent, 0.06 percent and 0.03 percent declines in headline, core and food inflation, respectively. This relationship could be so because declines in oil prices are usually accompanied by a moderation in the marginal cost of production in many countries. Given that Nigeria imports a significant amount of consumer and capital goods, a decline in the marginal cost of production in other countries would lessen import prices and subsequently ease inflationary pressures in the country. However, all the coefficients of oil price declines were not statistically significant.

Furthermore, growth in money supply was a significant contributor to increase in inflationary pressures in Nigeria, as estimated coefficients were significant at the 1 percent levels in both models 1 and 3. This justifies the quantity theory of money given that an increase in oil price leads to expansion in money supply which bears a direct positive relationship with inflation. Moreover, the coefficients of output gap have the anticipated positive signs and were significant at 1 percent levels in all the 3 models, indicating that positive output gap has been inflationary in line with economic theory. The results also revealed that nominal exchange rate depreciation leads to increases in inflation, confirming an incomplete pass-through effect. We expect agro-climatic conditions (rainfall) to significantly impact on inflation in Nigeria given the huge share of food commodities in Nigeria CPI. However, the coefficients of average rainfall carry the wrong signs in two of the models and were insignificant in all the models.

Empirical results from the short-run models are presented in Table 4. The coefficients of oil price increases are significant at the 5 percent and 10 percent levels in both the headline and the core inflation models. 
Table 4: Estimated Short-run Model

\begin{tabular}{|c|c|c|c|}
\hline Dependent Variable & $\Delta \ln ($ cpih $)$ & $\Delta \ln ($ cpic $)$ & $\Delta \ln (\mathrm{cpif})$ \\
\hline Variable & Model 1 & Model 2 & Model 3 \\
\hline \multirow[t]{2}{*}{$\Delta \ln ($ oilp)_pos } & $0.0412 * *$ & $0.0555^{*}$ & 0.0456 \\
\hline & $(0.0192)$ & $(0.0304)$ & $(0.0289)$ \\
\hline \multirow[t]{2}{*}{$\Delta \ln ($ oilp)_neg } & 0.0165 & 0.0164 & 0.0102 \\
\hline & $(0.0138)$ & $(0.0247)$ & $(0.0205)$ \\
\hline \multirow[t]{2}{*}{$\Delta \ln (\mathrm{m})$} & $0.0821 * * *$ & 0.0329 & $0.0980 * * *$ \\
\hline & $(0.0246)$ & $(0.0396)$ & $(0.0351)$ \\
\hline \multirow[t]{2}{*}{$\Delta$ qgap } & $0.0009 * * *$ & 0.0008 & $0.0013 * * *$ \\
\hline & $(0.0003)$ & $(0.0005)$ & $(0.0005)$ \\
\hline \multirow[t]{2}{*}{$\Delta$ qgap $(-1)$} & $-0.0019 * * *$ & $-0.0027 * * *$ & $-0.0018 * *$ \\
\hline & $(0.0006)$ & $(0.0009)$ & $(0.0008)$ \\
\hline \multirow[t]{2}{*}{$\Delta$ qgap(-2) } & $-0.0009 * * *$ & $-0.0012 * *$ & -0.0008 \\
\hline & $(0.0003)$ & $(0.0005)$ & $(0.0005)$ \\
\hline \multirow[t]{2}{*}{$\Delta \ln (\mathrm{er})$} & 0.0963 & 0.0736 & 0.0894 \\
\hline & $(0.0704)$ & $(0.1197)$ & $(0.1058)$ \\
\hline \multirow[t]{2}{*}{$\Delta \ln (\operatorname{er}(-1))$} & -0.0949 & -0.0279 & -0.0741 \\
\hline & $(0.0632)$ & $(0.1029)$ & $(0.0960)$ \\
\hline \multirow[t]{2}{*}{$\Delta \ln (\operatorname{er}(-2))$} & $-0.1852 * * *$ & $-0.1966^{*}$ & $-0.2235 * *$ \\
\hline & $(0.0626)$ & $(0.0997)$ & $(0.0966)$ \\
\hline \multirow[t]{2}{*}{$\Delta \ln ($ rain $)$} & $0.0084 * * *$ & -0.0015 & $0.0148 * * *$ \\
\hline & $(0.0026)$ & $(0.0046)$ & $(0.0041)$ \\
\hline \multirow[t]{2}{*}{$\Delta \ln (\operatorname{rain}(-1))$} & 0.0034 & 0.0134 & $0.0078^{*}$ \\
\hline & $(0.0027)$ & $(0.0081)$ & $(0.0043)$ \\
\hline \multirow[t]{2}{*}{$\Delta \ln (\operatorname{rain}(-2))$} & & $0.0095^{*}$ & \\
\hline & & $(0.0048)$ & \\
\hline \multirow[t]{2}{*}{ ecm(-1) } & $-0.3314 * * *$ & $-0.2704 * * *$ & $-0.3918 * * *$ \\
\hline & $(0.0578)$ & $(0.0718)$ & $(0.0778)$ \\
\hline \multirow[t]{2}{*}{ LM } & 0.51808 & 1.2671 & 0.6682 \\
\hline & $(0.723)$ & $(0.294)$ & $(0.617)$ \\
\hline \multirow[t]{2}{*}{$\mathrm{ARCH}$} & 1.6947 & 2.0598 & 2.2768 \\
\hline & $(0.164)$ & $(0.099)$ & $(0.073)$ \\
\hline \multirow[t]{2}{*}{ RESET } & 2.6041 & 0.7563 & 0.4509 \\
\hline & $(0.112)$ & $(0.388)$ & $(0.833)$ \\
\hline
\end{tabular}

$*, * *$ and $* * *$ indicate significance at 10 percent, 5 percent and 1 percent levels. Standard errors are in brackets

However, it was not significant in model 3 for food inflation and this could be attributed to the fact that imported food constitutes just about 26 percent of food in the CPI basket. Thus, this finding indicates that oil price increases do not manifest in food inflation in the short-run. The coefficients of oil price declines were positive but remain insignificant also in the short-run. 
The contemporaneous coefficients of money supply and output gap have the appropriate signs and remain significant in models 1 and 3 . However, exchange rate depreciation was positive and not significant, but its first and second lags turned negative, indicating that depreciation of the domestic currency has a lag effect on inflation in the short-run.

The error correction terms (ecm) are negative and found to be significant at the 1 percent levels across the three models, thereby providing additional evidence in favour of the presence of long-run relationships among the variables in the three models. The coefficients ranged between -0.2704 for model 2 and -0.3918 for model 3, indicating that about 27 percent to 39 percent of the deviations from equilibrium arising from the models are corrected within one (1) quarter. We check for serial correlation utilizing the residual serial correlation LM tests, and the results indicated that the residuals are free of autocorrelation in all the models. The ARCH test showed that the residuals from the three models are homoscedastic, while the Ramsey RESET tests indicated that the models are correctly specified. The CUSUM and CUSUMSQ tests were used to test if the models are stable. A model is deemed stable if its recursive residual is positioned within the two critical bounds. The results in appendix A1 showed that model 1 was stable, while relative instability was recorded in some periods in models 2 and 3 owing to significant declines in core inflation from 2013Q1 and a huge rise in food inflation from 2005Q1.

\subsection{Robustness Checks}

To check the robustness of our results to changes in the explanatory variables, we re-specify model 1 with the oil price increases and decreases as the explanatory variables to form model 4. Model 5 includes output gap while model 6 further added exchange rates. Model 7, however, comprised all the variables in model 1 except average rainfall. Results from the long-run analysis (appendix A2) shows that all the coefficients of oil price increases maintain the positive signs and were significant at the 5 percent levels. However, the coefficients of oil price declines turn negative and were significant at 1 percent levels in models 4 and 5 (when exchange rate was removed from the equations), indicating that decline in oil prices lead to increases in headline inflation during the period. This shows that the impact of oil price declines largely manifested on higher inflation through the exchange rates, and the relationship between oil price declines and higher inflation became visible in the long-run when the exchange rate variable is omitted from the models. These results largely corroborate the 
findings of Kelikume (2017), Bala and Chin (2018) and Omolade et al. (2019) that declines in oil prices were accompanied by increases in inflation in oil producing economies including Nigeria. A possible reason for this scenario is that decline in prices of crude oil in the international market results in significant declines in foreign exchange inflows to Nigeria, lower foreign exchange reserves and the tendency to witness higher demand pressures in the foreign exchange market relative to the short supply which ultimately lead to currency depreciation and rising inflation. The short-run analysis (Appendix A3) also shows that positive oil price shocks induce a rise in headline inflation, with the coefficients being significant at the 5 percent level in Models 6 and 7.

To analyse how changes in sample period may affect these relationships, we re-estimated Model 1 using quarterly data from 2005 to 2018 corresponding to the period when oil prices rose above US\$50 per barrel. Empirical results from the long-run analysis (Model 8) also disclosed that oil price hike increases headline inflation, and the coefficient was significant at the 1 percent level. Similarly, price declines induce an increase in headline inflation, though the coefficient was insignificant. Similarly, the coefficient of oil price hikes was positive and significant in the short-run, while the coefficient of oil price drops remained negative and insignificant.

\section{Conclusion and Policy Recommendations}

Fluctuations in oil prices at the international commodities market tend to affect all economies across the world including the oil producers. Global oil price shocks often impact domestic inflation in these economies through a number of channels. Given that Nigeria has abundant oil resources and hugely depends on those resources for foreign exchange earnings and government revenues, this study investigated the impact of oil price shocks on consumer price inflation in Nigeria. The study utilized the NARDL approach and quarterly data for the pe$\operatorname{riod} 1999-2018$.

Empirical results from the asymmetric analysis indicated that oil price increases significantly impact on headline, core and food inflation in Nigeria. These results suggest that global oil price increases tend to generate inflationary pressures in the country. Given the importance of oil in the production process, a rise in oil prices would increase the relative price of energy inputs leading to a rise in the cost of production in many countries, thereby increasing global inflationary pressures when the rising oil prices persist. The global oil-induced in- 
flation ultimately pass-through to Nigeria through imports. In addition, significant increases in oil prices are accompanied by transfer of income from oil consuming to oil producing economies, leading to economic booms in oil exporting countries. In Nigeria, higher oil price culminates in higher inflow of oil windfalls and larger government revenues accruing to the three tiers of government. This leads to significant increases in government outlays and rising inflationary pressures in the country. Similarly, rising oil prices culminates in an increase in money supply in Nigeria, leading to an equally rising inflation in such periods. With the recent removal of fuel subsidies and the periodic announcement of fuel prices in Nigeria, increases in international prices of crude oil would pass-through to domestic retail fuel prices, further aggravating inflationary pressures in the country.

Findings also showed that oil price increases have a higher positive impact on the core measure of inflation than food inflation during the study period. This is so because most of the food consumed are produced in the country with only about 26 percent of the food CPI imported from outside. Consequently, food prices are largely immune from the pass-through effects of global oil price-induced inflation.

Inflation also responds positively to oil price drops in the main models, suggesting that oil price declines lead to a moderation in domestic inflation in Nigeria. Declines in oil prices are usually accompanied by reduction in production costs in many countries and lower oil earnings and government revenues in Nigeria, which serve to lower domestic inflation. However, additional results from the robustness analysis showed that oil price declines culminated in higher inflation in the country when the exchange rate variable was dropped from the models. This was possible as periods of rapid declines in oil prices in Nigeria are, sometimes, accompanied by significant depletion in foreign exchange reserves and the tendency for excess demand in the foreign exchange market, culminating in the depreciation of the domestic currency and higher inflation.

Meanwhile, the relationship between oil price increases and headline inflation in Nigeria was found to be robust to changes in econometric specifications and sample period. These findings are essential guide for monetary policy management in Nigeria as it brings to the fore the need for the monetary authority to address mounting inflationary pressures in periods of oil price shocks. 
Given the observed differences in the impact of oil prices on core and food inflation and ultimately headline inflation, this study recommends that the monetary policy actions of the Central Bank of Nigeria (CBN) should be focused on addressing core inflation in periods of excessive oil price increases. The Central Bank should also strengthen its efforts aimed at increasing the domestic production of food items by providing/guaranteeing more funding through its intervention schemes in the agricultural sector, as this would help in further reduction in food imports thereby minimising the impact of oil price fluctuations on food inflation. In addition, there is need to ensure that the fiscal policy stance is not excessively procyclical in periods of rising oil prices, so as to complement the efforts of the monetary authority in moderating inflation. It is also recommended that the country should ensure the saving of excess oil proceeds and building of external reserve buffers in periods of rising crude oil prices. Savings of excess proceeds would avert the overheating of the economy owing to higher inflows thereby moderating the consequent inflationary pressures. External reserve buffers, however, would help in moderating excess demand and achieving stable exchange rate in the foreign exchange market during oil price declines. The Central Bank of Nigeria would also need to sustain the implementation of appropriate policies in the foreign exchange market with a view to achieving stable exchange rates and ensuring the efficient management of foreign reserves during periods of declining oil prices.

\section{References}

Abdlaziz, R. A., Rahim, K. A., \& Adamu, P. (2016). Oil and food prices co-integration nexus for Indonesia: A non-linear autoregressive distributed lag analysis. International Journal of Energy Economics and Policy 6(1), 82-87.

Abounoori, A. A., Nazarian, R., \& Amiri, A. (2014). Oil price pass-through into domestic inflation: The case of Iran. International Journal of Energy Economics and Policy $4(4), 662-669$.

Alhassan, A., \& Kilishi, A. A. (2016). Analysing oil price- macroeconomic volatility in Nigeria. CBN Journal of Applied Statistics 7(1a), 1-22.

Aliyu, S. U. (2009). Oil price shocks and the macroeconomy of Nigeria: A non-linear approach. Retrieved from https://mpra.ub.uni-muenchen.de/18726/1/MPRA_paper_18726.pdf

Alvarez, L. J., Hurtado, S., Sanchez, I., \& Thomas, C. (2011). The impact of oil price changes on Spanish and Euro area consumer price inflation. Economic Modelling 28 (1-2), 422-431. 
Bala, U., \& Chin, L. (2018). Asymmetric impacts of oil price on inflation: An empirical study of African OPEC member countries. Energies 2018, 11, 3017, 1-21.

Bataa, E. (2010). Impacts of oil shocks: Implications for GCC economies. Lancaster: Gulf One Lancaster Centre for Economic Research (GOLCER), Lancaster University Management School.

Bawa, S., Abdullahi, I. S., \& Ibrahim, A. (2016). Analysis of inflation dynamics in Nigeria (1981 - 2015). CBN Journal of Applied Statistics 7(1b), 255-276.

Bello, U. A., \& Sanusi, A. R. (2019). Inflation dynamics and exchange rate pass-through in Nigeria: Evidence from augmented nonlinear new Keynesian Philips curve. CBN Journal of Applied Statistics 10(2), 109 - 138.

Blanchard, O. J., \& Gali, J. (2007). The macroeconomic effects of oil price shocks: Why are the 2000s so diffirent from the 1970s? Economics Working Papers 1045, Department of Economics and Business, Universitat Pompeu Fabra.

Blanchard, O. J., \& Riggi, Y. (2013). Why are the 2000s So Diffirent from the 1970s? A structural interpretation of changes in the macroeconomics effects of oil prices. Journal of the European Economic Association 11(5), 1032-1052.

Brown, S. P., Oppedahl, D. B., \& Yucel, M. K. (1995). Oil prices and inflation. Research Department Working Paper 95 - 10, Federal Reserve Bank of Dallas.

Calvo, G. A. (1983). Staggered prices in a utility-maximising framework. Journal of Monetary Economics 12, 383-398.

Cevik, S., \& Teksoz, K. (2013). Hitchhiker's guide to inflation in Libya. IMF Working Paper Series WP/13/78 International Monetary Fund.

Choi, S., Furceri, D., Loungani, P., Mishra, S., \& Poplawski-Ribeiro, M. (2018). Oil prices and inflation dynamics: Evidence from advanced and developing economies. Journal of International Money and Finance 82, 71-96.

Conflitti, C., \& Luciani, M. (2017). Oil price pass-through into core inflation. Bank of Italy Occasional Paper No. 405.

Cunado, J., \& de Gracia, P. F. (2005). Oil prices, economic activity and inflation: Evidence for some asian countries. Quarterly Review of Economics and Finance 45, 65-83.

DePratto, B., Resende, C., \& Maier, P. (2009). How changes in oil prices affect the macroeconomy. Bank of Canada Working Paper 2009-33.

Dias, F. C. (2013). Oil price shocks and their effects on economic activity and prices: An application for Portugal. Banco de Portugal Economic Bulletin, Summer 2013, 39 48 . 
Fried, E., \& Schultze, C. (1975). Higher oil prices and the World economy. Washington DC: The Brookings Institution.

Hamilton, J. D. (1983). Oil and the macroeconomy since World War II. The Journal of Political Economy 91(2), 228-248.

Hamilton, J. D. (1996). This is what happened to the oil price-macroeconomy relationship. Journal of Monetary Economics 38, 215-220.

Hamilton, J. D. (2005). Oil and the macroeconomy. Prepared for: Palgrave Dictionary of Economics.

Hooker, M. A. (2002). Are oil shocks inflationary? Asymmetric and non-linear specifications versus changes in regimes. Journal of Money, Credit, and Banking 34(2), $540-561$.

Ibrahim, M. H. (2015). Oil and food prices in Malaysia: A non-linear ardl analysis. Agricultural and Food Economics 3(2), 1-14.

International Monetary Fund (2000). The impact of higher oil prices on the global economy. Retrieved from https://www.imf.org/external/pubs/ft/oil/2000/oilrep.PDF

Ito, K. (2010). The impact of oil price volatility on macroeconomic activity in Russia. Economic Analysis Working Papers 9(5), Economists Association of A Coruña.

Kelikume, I. (2017). Do exchange rate and oil price shocks have asymmetric effect on inflation?: Some evidence from Nigeria. The Journal of Developing Areas 51(4), 271283.

Lacheheb, M., \& Sirag, A. (2019). Oil price and inflation in Algeria: A non-linear ardl approach. The Quarterly Review of Economics and Finance 73, 217-222.

Lu, W., Liu, T., \& Tseng, C. (2013). Volatility transmissions between shocks to the oil price and inflation: evidence from a bivariate GARCH Approach. Journal of Information and Optimization Sciences 31(4), 927-939.

Marquez, J. (1986). Oil-Price effects in theory and practice. Journal of Development Economics 24, 1 - 27.

Mork, K. A. (1989). Oil and the macroeconomy when prices go up and down: An extension of Hamilton's results. Journal of Political Economy 97, 740-744.

Mory, J. F. (1993). Oil prices and economic activity: Is the relationship symmetric? The Energy Journal 14(4), 151-161.

Niyimbanira, F. (2013). An investigation of the relationship between oil prices and inflation in South Africa. Mediterranean Journal of Social Sciences 4(6), 105-111. 
Odionye, J. C., Ukeje, O. S., \& Odo, A. C. (2019). Oil price shocks and inflation dynamics in Nigeria: Sensitivity of unit root to structural breaks. International Journal of Business and Economics Research 8(2), 58-64.

Olusegun, O. A. (2008). Oil price shocks and the Nigerian economy: A forecast error variance decomposition analysis. Journal of Economic Theory 2(4), 124-130.

Omolade, A., Ngalawa, H., \& Kutu, A. (2019). Crude oil price shocks and macroeconomic performance in Africa's oil-producing countries. Cogent Economics \& Finance (7), $1-17$.

Omotosho, B. S. (2019). Oil price shocks, fuel subsidies and macroeconomic (in)stability in Nigeria. CBN Journal of Applied Statistics 10(2), 1 - 38.

Omotosho, B. S., \& Doguwa, S. I. (2012). Understanding the dynamics of inflation volatility in Nigeria: A GARCH perspective. CBN Journal of Applied Statistics 3(2), 51 74.

Oyeyemi, A. M. (2013). The growth implications of oil price shock in Nigeria. Journal of Emerging Trends in Economics and Management Sciences (JETEMS) 4(3), 43-349.

Pesaran, M., Shin, Y., \& Smith, R. (2001). Bounds testing approaches to the analysis of level relationships. Journal of Applied Econometrics 16(3), 289-326.

Rondina, F. (2017). The impact of oil price changes in a new Keynesian model of the u.s. economy. Department of Economics University of Ottawa Working Paper 1709.

Rotemberg, J. J., \& Woodford, M. (1999). The cyclical behavior of prices and costs. NBER Working Paper 6909.

Sek, S. K., \& Lim, H. S. (2016). An investigation on the impacts of oil price shocks on domestic inflation: A SVAR approach . AIP Conference Proceedings 1750, 060002 (2016).

Sek, S. K., Teo, X. Q., \& Wong, Y. N. (2015). A comparative study on the effects of oil price changes on inflation. Procedia Economics and Finance 26 (2015), 630 - 636.

Shafique, M. J. (2016). Plunging crude oil prices and its effects on inflation in Pakistan. Journal of Energy Technologies and Policy 6(10), 36-41.

Shin, Y., Yu, B., \& Greenwood-Nimmo, M. (2014). Modeling asymmetric cointegration and dynamic multipliers in a non-linear ardl framework. In R. Sickles, \& W. Horrace, Festschrift in Honour of Peter Schmidt. New York, NY: Springer.

Trang, N. T., Tho, T. N., \& Hong, D. T. (2017). The impact of oil price on the growth, inflation, unemployment and budget deficit of Vietnam. International Journal of Energy Economics and Policy 7(3), 42-49. 
Zhao, L., Zhang, H., Wang, S., \& Xu, S. (2016). The effects of oil price shocks on output and inflation in China. Energy Economics 53, 101-110.

Zivkov, D., Duraskovic, J., \& Manic, S. (2019). How do oil price changes affect inflation in Central and Eastern European countries? A wavelet-based Markov switching approach. Baltic Journal of Economics 19(1), 84-104.

\section{Appendix A1: CUSUM and CUSUMSQ for the 3 Models}

Model 1

Plot of Cumulative Sum of Rearsive Resicials

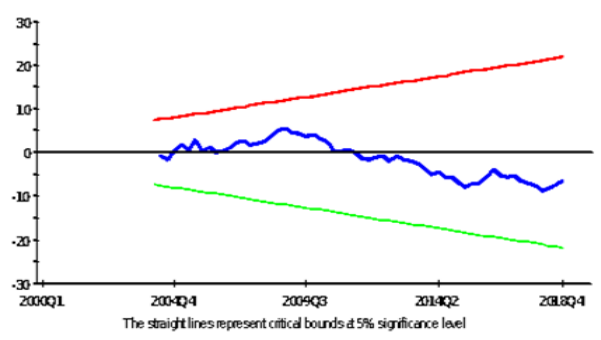

Pot of Cumulative Sum of Rearsive Residals

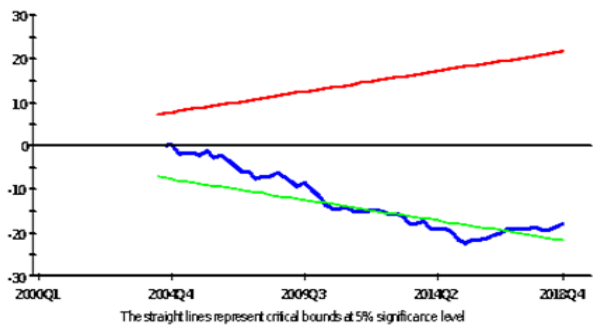

Plot of Cumulative Sumof Reoursive Residals

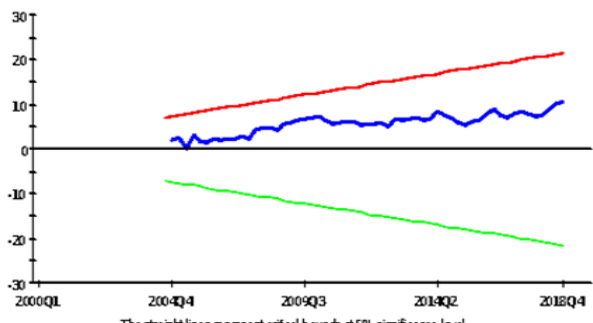

Plot of Cumuative Sumof Squares of Recursive Residals

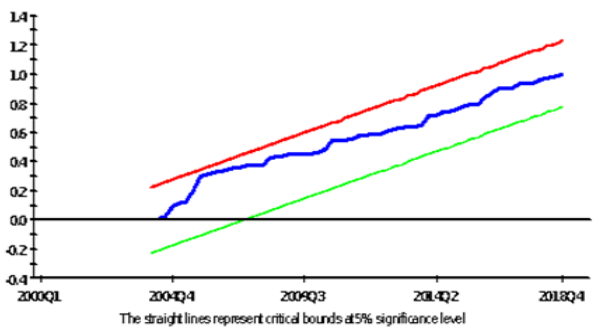

Model 2

PlotofCumulabive Sum of Squares of Recursive Residals

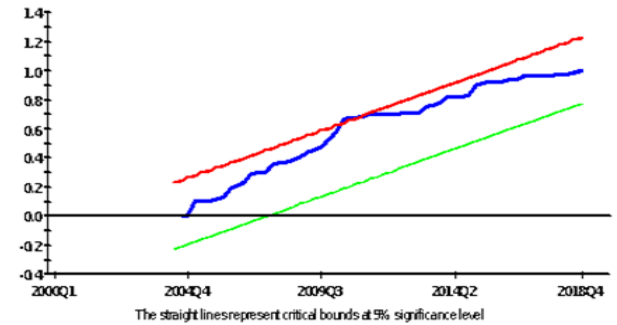

Model 3

Plot of Cumulative Sum of Sqares of Recursive Residals

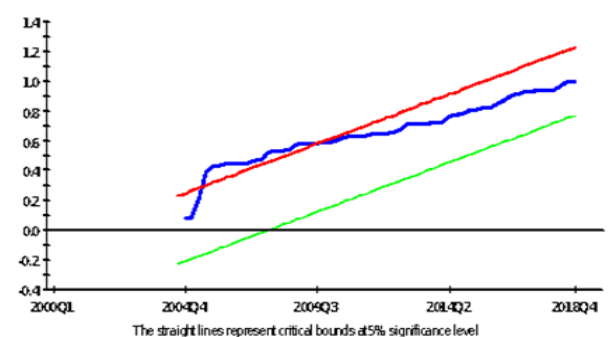


Appendix A2: Sensitivity Analysis (Long-run Model)

\begin{tabular}{|c|c|c|c|c|c|}
\hline $\begin{array}{l}\text { Dependent } \\
\text { Variable }\end{array}$ & $\ln ($ cpih $)$ & $\ln (\mathrm{cpih})$ & $\ln ($ cpih) & $\ln ($ cpih $)$ & $\ln ($ cpih $)$ \\
\hline Variable & Model 4 & Model 5 & Model 6 & Model 7 & Model 8 \\
\hline $\mathrm{c}$ & $\begin{array}{l}3.7058 * * * \\
(0.1948)\end{array}$ & $\begin{array}{l}3.7169 * * * \\
(0.2069)\end{array}$ & $\begin{array}{l}1.6305 \\
(1.0286)\end{array}$ & $\begin{array}{l}-1.7958 * * \\
(0.8488)\end{array}$ & $\begin{array}{l}0.2715 \\
(0.9986)\end{array}$ \\
\hline $\ln ($ oilp)_pos & $\begin{array}{l}0.2031 * * * \\
(0.0722)\end{array}$ & $\begin{array}{l}0.2035^{* * *} \\
(0.0750)\end{array}$ & $\begin{array}{l}0.2920 * * * \\
(0.0553)\end{array}$ & $\begin{array}{l}0.1728 * * \\
(0.0651)\end{array}$ & $\begin{array}{l}0.2312 * * * \\
(0.0640)\end{array}$ \\
\hline $\ln ($ oilp)_neg & $\begin{array}{l}- \\
0.2647 * * * \\
(0.0891)\end{array}$ & $\begin{array}{l}- \\
0.2633 * * * \\
(0.0924)\end{array}$ & -0.0532 & 0.0469 & -0.0648 \\
\hline $\ln (m)$ & & & & $\begin{array}{l}0.1817 * * \\
(0.0802)\end{array}$ & $\begin{array}{l}0.0469 \\
(0.0913)\end{array}$ \\
\hline qgap & & $\begin{array}{l}-0.0011 \\
(0.0013)\end{array}$ & $\begin{array}{l}-0.0009 \\
(0.0010)\end{array}$ & $\begin{array}{l}0.0132 * * * \\
(0.0029)\end{array}$ & $\begin{array}{l}0.0107 * * * \\
(0.0024)\end{array}$ \\
\hline $\ln (\mathrm{er})$ & & & $\begin{array}{l}0.4072^{*} \\
(0.2167)\end{array}$ & $\begin{array}{l}0.8508 * * * \\
(0.1270)\end{array}$ & $\begin{array}{l}0.5733 * * * \\
(0.1151)\end{array}$ \\
\hline $\ln ($ rain $)$ & & & & & $\begin{array}{l}0.0379 * * * \\
(0.0115)\end{array}$ \\
\hline
\end{tabular}

$*, * *$ and $* * *$ indicate significance at 10 percent, 5 percent and 1 percent levels. Standard errors are in brackets 
Appendix A3: Sensitivity Analysis (Short-run Model)

\begin{tabular}{|c|c|c|c|c|c|}
\hline $\begin{array}{l}\text { Dependent Vari- } \\
\text { able }\end{array}$ & $\ln ($ cpih) & $\ln ($ cpih $)$ & $\ln ($ cpih $)$ & $\ln ($ cpih) & $\ln ($ cpih $)$ \\
\hline Variable & Model 4 & Model 5 & Model 6 & Model 7 & Model 8 \\
\hline$\Delta \ln ($ oilp)_pos & $\begin{array}{l}0.0214 \\
(0.0140)\end{array}$ & $\begin{array}{l}0.0207 \\
(0.0140)\end{array}$ & $\begin{array}{l}0.0399 * * \\
(0.0176)\end{array}$ & $\begin{array}{l}0.0596 * * \\
(0.0271)\end{array}$ & $\begin{array}{l}0.1344 * * * \\
(0.0370)\end{array}$ \\
\hline$\Delta \ln ($ oilp)_neg & $\begin{array}{l}0.0243 \\
(0.0275)\end{array}$ & $\begin{array}{l}0.0220 \\
(0.0276)\end{array}$ & $\begin{array}{l}-0.0073 \\
(0.0139)\end{array}$ & $\begin{array}{l}0.0134 \\
(0.0308)\end{array}$ & $\begin{array}{l}-0.0211 \\
(0.0171)\end{array}$ \\
\hline$\Delta \ln (\mathrm{m})$ & & & & $\begin{array}{l}0.0861 * \\
(0.0455)\end{array}$ & $\begin{array}{l}0.1095 * * * \\
(0.0389)\end{array}$ \\
\hline$\Delta$ qgap & & $\begin{array}{l}-0.0001 \\
(0.0001)\end{array}$ & $\begin{array}{l}-0.0001 \\
(0.0001)\end{array}$ & $\begin{array}{l}0.0011 * * * \\
(0.0004)\end{array}$ & $\begin{array}{l}0.0011 * * * \\
(0.0003)\end{array}$ \\
\hline$\Delta$ qgap $(-1)$ & & & & $\begin{array}{l}-0.0023 * * * \\
(0.0007)\end{array}$ & $\begin{array}{l}-0.0015 * * \\
(0.0006)\end{array}$ \\
\hline$\Delta$ qgap(-2) & & & & $\begin{array}{l}-0.0012 * * * \\
(0.0004)\end{array}$ & $\begin{array}{l}-0.0006^{*} \\
(0.0003)\end{array}$ \\
\hline$\Delta \ln ($ er $)$ & & & $\begin{array}{l}0.0556 \\
(0.0336)\end{array}$ & $\begin{array}{l}0.0680 \\
(0.0857)\end{array}$ & $\begin{array}{l}0.0720 \\
(0.0725)\end{array}$ \\
\hline$\Delta \ln (\operatorname{er}(-1))$ & & & & $\begin{array}{l}-0.2098 * * \\
(0.0785)\end{array}$ & $\begin{array}{l}-0.1207 * * \\
(0.0591)\end{array}$ \\
\hline$\Delta \ln (\operatorname{er}(-2))$ & & & & $\begin{array}{l}-0.2051^{* *} \\
(0.0747)\end{array}$ & $\begin{array}{l}-0.1282 * * \\
(0.0582)\end{array}$ \\
\hline$\Delta \ln ($ rain $)$ & & & & & $\begin{array}{l}0.0123 * * * \\
(0.0029)\end{array}$ \\
\hline $\begin{array}{l}\Delta \ln (\text { rain }(-1)) \\
\Delta \ln (\text { rain }(-2))\end{array}$ & & & & & \\
\hline ecm(-1) & $\begin{array}{l}-0.1056^{* *} \\
(0.0413)\end{array}$ & $\begin{array}{l}-0.1016^{* *} \\
(0.0415)\end{array}$ & $\begin{array}{l}-0.1366 * * * \\
(0.0475)\end{array}$ & $\begin{array}{l}0.3448 * * * \\
(0.0770)\end{array}$ & $\begin{array}{l}-0.3252 * * * \\
(0.0735)\end{array}$ \\
\hline
\end{tabular}

$*, * *$ and $* * *$ indicate significance at 10 percent, 5 percent and 1

percent levels. Standard errors are in brackets 